\title{
ON CALAMINE CRYSTALS FROM MEXICO, RUTILE-MICA INTERGROWTH FROM CANADA, AND PSEUDOMORPHS OF MARCASITE AFTER PYRRHOTITE FROM PRUSSIA.
}

\author{
By Joseph E. Pogue, \\ Assistant Curator, Division of Mineralogy, U. S. National Museum.
}

\section{CALAMINE CRYSTALS FROM CHIHUAHUA, MEXICO.}

Calamine crystals of unusual perfection from Chihuahua, Mexico, acquired in April, 1910, by the United States National Museum (Catalogue No. 86662), show the following faces: $c(001), b(010), m(110)$, $e(011), i(031), s(101), t(301), u(211)$, and $v(121)$, the last appearing only on the antigolous pole. The crystals are clear and colorless, with tabular development parallel to $b(010)$, and vary in size up to 11 by 4 by $1 \mathrm{~mm}$. for their greatest dimensions. Figures 1, 2, and 3, plate 63 , show the actual development of three individuals, at the same time representing the three phases or habits to which all the crystals may be referred. Phase 1 , of which figure 1 is typical, often lacks the base $c(001)$ and is chiefly characterized by a symmetrical development, the presence of $u(211)$, and a wedgelike top elongated parallel to the $a$-axis owing to a prominent development of the brachydomes. Crystals from the Organ Mountains, Dona Ana County, New Mexico, ${ }^{a}$ and from Altenberg, Belgium, ${ }^{b}$ resemble this phase. Occasionally the two pairs of domes are almost equally developed, a resulting squarish cast being then given the crystal. Phase 2 , represented by figure 2 , is terminated at its lower end in only one instance; aside from this, its chief characteristics are the pointed character of its apex, its rather unsymmetrical development, and relatively great length. Phase 3, as shown in figure 3 , has a wedge-like upper termination, formed by the prominent development of the macrodomes $s(101)$ and $t(301)$, to the almost

$a$ W. E. Ford and F. Ward. Calamine crystals from the Organ Mountains, Dona Ana County, New Mexico. [In Mineral Notes.] Amer. Jour. Sci., vol. 28, 1909, pp. $185,186$.

b C. Hintze. Handbuch der Mineralogie, vol. 2, 1897, pp. 1317-1319. 
complete repression of the brachydomes $e(011)$ and $i(031)$. This phase, too, shows what appears to a less extent among most all the crystals, namely, striated side pinacoid faces, due to oscillatory combination of $b(010)$ and $m(110)$. The $t(301)$ faces in all three phases are frequently lightly striated horizontally.

\section{A BIOTITE-PHLOGOPITE-RUTILE INTERGROWTH SHOWING ASTERISM FROM OTTAWA, CANADA.}

The regular growth of one mica within another is a not infrequent occurrence. Inclusions of biotite in muscovite, and muscovite in biotite, of lepidolite in muscovite and the reverse, and of biotite in phlogopite, are known from a number of localities. For example, biotite in muscovite from Alstead, New Hampshire, and biotite inclosed in phlogopite from South Burgess and Grenville, Canada, and West Chester, Pennsylvania, have been described by Rose. ${ }^{a}$ Lasaulx ${ }^{b}$ has given a full account of intergrowths of muscovite and biotite occurring at Middletown, Connecticut. Lewis ${ }^{c}$ has discussed the inclosures of biotite in muscovite among the micas of West Philadelphia. Sheets of muscovite containing hexagonal plates of biotite have been noted by Leidy ${ }^{d}$ from Macon County, North Carolina. $\mathrm{Kunz}^{e}$ has mentioned that slender crystals of biotite were found inclosed in muscovite at Stoneham, Maine. Bowman ${ }^{f}$ has discussed in detail the intergrowths of muscovite and lepidolite occurring at Haddam Neck in Connecticut. Of these and additional examples, specimens from Middletown, Connecticut; hexagonal sheets of biotite included in muscovite from Buck Creek, Macon County, North Carolina; rhombic plates of muscovite in biotite from Custer County, South Dakota; and intergrowths of muscovite and lepidolite from Mount Apatite, Auburn, Maine, are represented in the U. S. National Museum collections. ${ }^{g}$ The various inclusions vary from several inches in diameter to those of microscopic dimensions, and appear mostly as thin plates within larger sheets, with mutual regularity of

$a$ G. Rose. Ueber die regelmässigen Verwachsungen der verschiedenen Glimmerarten unter einander sowie mit Pennin und Eisenglanz. Monatsb. kon. preuss. Acad., Berlin, 1869, pp. 339-362.

$b$ A. v. Lasaulx. Ueber eine Verwachsung zweier Glimmer von Middletown, Connecticut. Neues Jahrb. Min. Geol. Pal., 1878, pp. 630-635.

$c$ H. C. Lewis. On some inclosures in muscovite. Proc. Acad. Nat. Sci. Phila., 1882, pp. 311-315.

$d$ J. Leidy. On topaz and biotite. Proc. Acad. Nat. Sci. Phila., vol. 34, 1882, p. 261.

e G. F. Kunz. Minerals from Stoneham, Maine. Amer. Jour. Sci., vol. 27, 1884, pp. 212-216.

$f$ H. L. Bowman. On an occurence of minerals at Haddam Neck, Connecticut, U. S. A. Mineral Mag., vol. 13, 1902, pp. 77-121; Zeitschr. f. Kryst., vol. 37, 1903, pp. 97-119.

$g$ Catalogue numbers $14349,13699,83775$, and 80230 , respectively. 
orientation, as shown by crystal outline, position of optic axes, and direction of the three rays of a percussion figure produced when a cleavage plate is struck by a sharp-pointed instrument.

Thick crystals of intergrown micas are much rarer than the intergrown sheets, with which the above citations have chiefly to do. Of such a kind is an example from Ottawa, Canada, in the Shepard collection of the U.S. National Museum (Cat. No. 195). Figure 4, plate 63 , is a clinographic projection of this crystal in natural size and development, accompanied by a plan of both its upper and lower basal planes. The stippled portion is biotite; the white, phlogopite. The form is that of biotite and the faces $c(001), O(112), \mu(111)$, and $b(010)$ are well developed and easily identifiable by contact measurement. The angles for phlogopite are so nearly identical with biotite that probably the same faces are represented on the included phlogopite crystal. It is notable that of the comparatively large number of faces capable of occurring on biotite, only those are found which are included among the much fewer known forms of phlogopite. The biotite has a very small optic angle; the phlogopite a still smaller one, appearing almost uniaxial. The two optic planes, however, may be seen to be parallel, both lying in the plane of symmetry (010) and parallel to the $b$ faces.

Chiefly within the phlogopite, but to a less extent running irregularly out into the biotite, there are visible under the microscope multitudinous inclusions of minute needles, most of which cross at angles of $60^{\circ}$, forming a triangular pattern. A less number, however, are arranged at right angles to the three main sets, and others are at random. These needles are of extreme thinness and so interleaved in the basal cleavage of the mica that successive ones may be brought into focus through the vertical extent of the thinnest obtainable cleavage sheet.

For their optical study and determination they were isolated from the mica by attacking the latter with hydrofluoric and heating the partly decomposed residue with strong nitric acid, whereby the needles were obtained floating in the liquid, completely freed from their host, and could be transferred by proper manipulation to a slide.

The inclusions were themselves unaffected by such violent treatment, ${ }^{a}$ and when in suspension their uncorroded faces reflected the light in prismatic colors, due to the excessive thinness of the reflecting surfaces.

Viewed under high magnification, the needles are seen to have a varied habit, occurring principally as long, slender laths with square or pointed terminations; but also in the form of rhombs, rectangles, distorted six-sided plates, wedges, knee-shaped twins, and so on (see 
accompanying figure). Numerous angular measurements were made, but the values were not constant, due doubtless to the restricted quarters of growth, so that the form is no absolute criterion for iden-

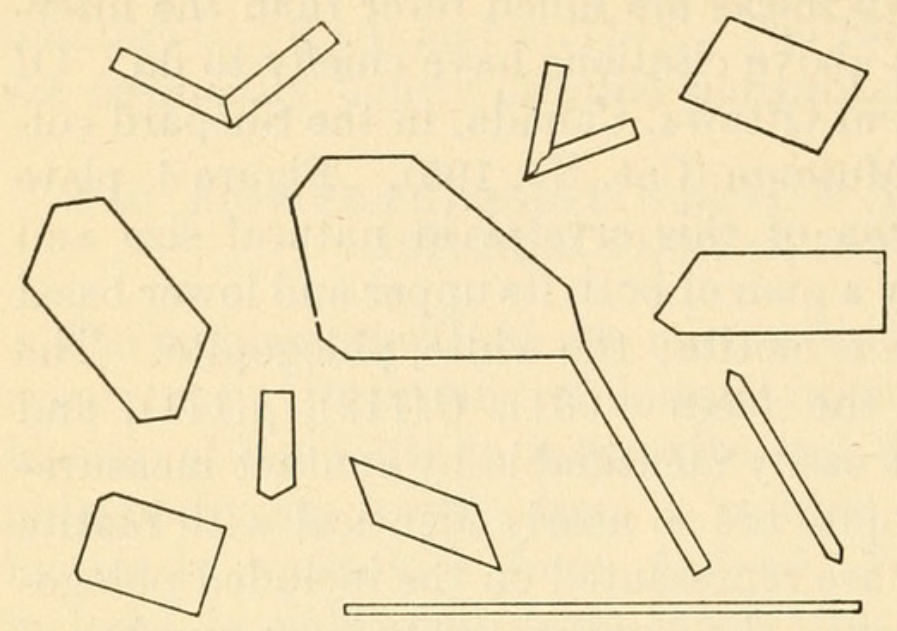

CharaCteristic SHapes OF THE RUTILE INCLUSIONS IN MiCA GREATLY MAdNIFIED. tification. The mineral is brightly and delicately colored, showing shades of green, purple, blue, red, and yellow, with often a gradation in colors along the length of a single crystal. The pleochroism is usually weak, but occasionally strong: $\mathfrak{c}=$ dark green to brown; $\mathfrak{a}=$ pale gray. The extinction is parallel and the crystals positively elongated. Absorption is $\mathfrak{c}>\mathfrak{a}$, which corresponds to $\varepsilon>\omega$; birefringence high. The index of refraction, determined by immersion, ${ }^{a}$ is considerably greater than 1.82 .

These features and the resistance to chemical attack eliminate other possibilities and concur in identifying the mineral as rutile.

Analogous inclusions in mica have been described from several localities, but the conclusions regarding their nature are diverse. The much discussed inclusions causing asterism in mica from South Burgess, Canada, were described and figured in detail by Rose, ${ }^{b}$ who originally considered these to be cyanite, but later concurred in the opinion of De Cloizeaux that they represented an uniaxial mica. An examination of specimens from this locality, and a consideration of Rose's abundant figures, leaves no doubt that his inclusions are also rutile.

Tschermak, ${ }^{c}$ in 1878 , studied the needles causing asterism in phlogopite from Perth, Canada, and from their refraction and form concluded that they could not be a mica, but was unable to determine their real nature.

Sanberger ${ }^{d}$ in 1881 noted rutile needles in a dark mica, altering to chlorite, from Bordenmais, and in the following year ${ }^{e}$ described a

$a$ The writer is indebted to Dr. F. E. Wright, of the Carnegie Geophysical Laboratory, for kindly making this determination.

$b$ G. Rose. Ueber die regelmassigen Verwachsungen der verschiedenen Glimmerarten unter einander sowie mit Pennin und Eisenglanz. Monatsb. kon. preuss. Acad. Berlin, 1869, pp. 339-362.

$c$ G. Tschermak. Die Glimmergruppe. Sitzungb. Akad. Wiss. Wien, vol. 76, 1877, p. 125; Zeitschr. f. Kryst., vol. 2, 1878, pp. 14, 15.

$d$ F. Sanberger. [Note.] Neues Jahrb. Min. Geol. Pal., vol. 1, 1881, pp. 258, 259.

$e$ F. Sanberger. Ueber Rutile in Phlogopite, etc. Neues Jahrb. Min. Geol. Pal., vol. 2, 1882, pp. 192. 193. 
phlogopite from Ontario, Canada, containing a network of colorless crystals, crossing at angles of $60^{\circ}$, which he proved chemically to be pure titanium dioxide. He thought this rutile to be a product of decomposition, because it increased in abundance with the degree of alteration of the mica.

Rosenbusch $^{a}$ in 1885 attributed the asterism of the Canadian micas chiefly to the presence of tourmalines of microscopic dimensions, though adding that in some instances rutile is present, causing asterism.

Lacroix ${ }^{b}$ the same year made a study of the inclusions in phlogopite from Templeton, Canada. These he succeeded in isolating by treatment with hydrochloric acid in a closed vessel heated to $250^{\circ}$, and obtained with them a strong qualitative test for titanium. In $1889^{\circ}$ he noted similar inclusions in a phlogopite from Ceylon.

In 1890 Clarke and Schneider ${ }^{d}$ submitted a sample of Burgess phlogopite to W. Lindgren for microscopic examination of its inclusions. It was concluded that the needles corresponded well in their optical properties with tourmaline, but no boron could be found in the mica to prove its presence.

Osann ${ }^{e}$ in 1899 became interested in the inclusions in phlogopite from Ottawa. He found these to occur as laths and variously shaped plates, with parallel extinction and positive elongation, which were unattacked by hydrofluoric acid and would scratch glass. These data being insufficient for identification, he submitted 0.0466 grain for chemical determination to Professor Jannasch, of Heidelberg, who reported $\mathrm{ZrO}_{2}$ (?), $\mathrm{TiO}_{2}$ (yellow coloration with $\mathrm{H}_{2} \mathrm{O}_{2}$ ), $\mathrm{K}, \mathrm{Na}$, traces of $\mathrm{Fe}$, and $\mathrm{H}_{2} \mathrm{O}$ (?), and thought that the mineral could not be rutile because the $\mathrm{H}_{2} \mathrm{O}_{2}$ reaction was "much too weak." No definite conclusion was therefore reached.

Canaval $^{f}$ in 1901 mentioned the occurrence of sagenetic rutile needles within the biotite of a garnet and graphite gneiss from Lading, Carinthia, but did not give the data upon which he based his determination.

The writer has examined a number of Canadian phlogopites showing asterism, and has found in each instance inclusions identical with

${ }^{a}$ H. Rosenbusch. Microscopische Physiographie, 1885, p. 487.

$b$ A. Lacroix. Sur les inclusions de la phlogopite de Templeton (Canada). Bull. Soc. Min. France, vol. 8, 1885, pp. 99-102.

$c$ A. Lacroix. Contributions a l'etude des gneiss a pyroxene et des roches a wernerite. Bull. Soc. Min. France, vol. 12, 1889, pp. 341, 342.

$d$ F. W. Clarke and E. A. Schneider. Experiments upon the constitution of the natural silicates. Pt. 5, The Micas. Amer. Journ. Sci., vol. 40, 1890, pp. 411, 412.

$e$ A. Osann. Notes on certain Archaean rocks of the Ottawa Valley. Geol: Surv. Canada, vol. 12, 1899, pt. O, pp. 1-84.

$f$ R. Canaval. Bemerkungen über das Kiesvorkommen von Lading. Jahrb. naturh. Mus. von Kärnten, vol. 26, 1901, pp. 1-9. 
those in the specimen here described, which itself shows marked asterism. ${ }^{a}$ The conclusion therefore seems warranted that asterism is generally due to the inclusion of regularly arranged rutile laths.

\section{PSEUDOMORPHS OF MARCASITE AFTER PYRRHOTITE FROM OSNABRÜCK, PRUSSIA.}

In November, 1909, the specimens here described were given to the U. S. National Museum (Catalogue No. 86666) by Mr. Werthmann, of Osnabrück, who called them "pseudomorphs of marcasite after an unknown mineral," and requested their more accurate determination. A careful study revealed the original mineral to be pyrrhotite, and this conclusion was made known to Mr. Werthmann. In the meantime Messrs. F. Schöndorf and R. Schroeder had reached the same conclusion regarding similar specimens, having published their results under the title Ueber Markasit von Hannover und Osnabrück in the Zweiter Jahresbericht des Niedersachsischen geologischen Vereins, Hannover, for 1909, pages 132 to 139, a copy of which was kindly sent to the present writer by Mr. Werthmann. Inasmuch, however, as this publication is one not readily accessible to English readers, and owing to the theoretical interest that pertains to the rare change of one iron sulphide into another, it is ventured to give the present account, even at the risk of some degree of repetition.

Plate 64 illustrates very completely the appearance and form of the marcasite. It may there be seen that this mineral occurs in single hexagonal pyramids, occasionally terminated by basal planes, and in larger, irregular masses and groups of crystals. The pyramidal faces are dull, usually rough, and frequently striated horizontally from repeated oscillatory combinations of the upper and lower pyramids. The basal planes are smooth, though almost without luster. In size the specimens range from 4 to $21 \mathrm{~mm}$. in greatest length.

The mineral is sharply differentiated from pyrrhotite and established as a form of iron disulphide by its color, hardness, density of 4.80-4.86, chemical composition, ${ }^{b}$ lack of magnetism, and ability to yield much sulphur in the closed tube. Its identification as marcasite instead of pyrite, however, is not absolutely without question. Its density and the fact that much free sulphur is left when its powder is dissolved in strong nitric acid are indicative of marcasite. Several crystals were sliced and a polished surface studied under the micro-

$a$ When a small flame was viewed through a fairly thin sheet, a well-marked sixrayed star was visible, with a secondary similar but less prominent star intermediate in position.
$b \quad \mathrm{Fe}=47.22 \%$.
$\mathrm{S}=52.61 \%$
M. Dittrich, analyst; quoted by Schöndorf and Schroeder;
Gangue $=.30$ Ueber Markasit von Hannover und Osnabrück. Zweiter Jahresb. Niedersachsischen geol. Vereins, Hannover, 1909, pp. 132-139.

100.13 
scope alongside of similarly prepared specimens of known marcasite and pyrite. The pseudomorphs are compact and homogeneous, with no perceptible core of pyrrhotite. The structure is similar to that of the marcasite examined, but the color was found to be intermediate between the two standard specimens, but on the whole inclining more to white than to yellow, and distinctly white in the case of the smaller crystals. The comparisons were, of course, made after cleaning with hydrochloric acid. The color, therefore, is the only doubtful point in the sure determination of the mineral as marcasite; but a careful weighing of the evidence and consideration of the work of Julien, ${ }^{a}$ Stokes, ${ }^{b}$ and others renders the identification as marcasite reasonably conclusive.

The determination of the crystal form as that of pyrrhotite is based upon the identification of the faces $c(0001)$ and $z(20 \overline{2} 1)$ (see figs. 5 and 6 , pl. 63) according to the following data:

\begin{tabular}{|c|c|c|c|c|c|}
\hline & $\begin{array}{l}\text { Average of } 8 \text { meas- } \\
\text { urements. Re- } \\
\text { flection goniom- } \\
\text { eter. }\end{array}$ & $\begin{array}{l}\text { A verage of } 5 \text { meas- } \\
\text { urements. Re- } \\
\text { flection goniom- } \\
\text { eter. }\end{array}$ & $\begin{array}{l}\text { Average of } 7 \text { meas- } \\
\text { urements. Con- } \\
\text { tact. }\end{array}$ & $\begin{array}{l}\text { A verage of } 5 \text { meas- } \\
\text { urements. Con- } \\
\text { tact. }\end{array}$ & $\begin{array}{l}\text { Theoretical for } \\
\text { pyrrhotite. }\end{array}$ \\
\hline $\begin{array}{l}c: z \ldots \ldots \\
z: z \ldots \ldots\end{array}$ & $\begin{array}{r}63^{\circ} 52^{\prime} \\
\ldots \ldots \ldots\end{array}$ & $\cdots \cdots \cdots 2^{\circ} 46^{\prime}$ & $\begin{array}{r}64^{\circ} \\
\ldots\end{array}$ & $53^{\circ}$ & $\begin{array}{l}63^{\circ} 32^{\prime} \\
53^{\circ} 11^{\prime}\end{array}$ \\
\hline
\end{tabular}

The measurements were obtained with difficulty, as the crystals were poorly adapted for giving reflections. The signals for the smoothest faces were blurred and the centers had to be approximated. In some instances the reflection was aided by the application of a thin coat of shellac to the faces to be measured; in other instances signals were obtained from minute pieces of glass cemented to the faces; but such measurements were only used when checked around the entire crystal. A general coincidence from the several methods and agreement with results obtained by contact offset the unreliability of any individual measurement. The possibility that the crystal form is orthorhombic, with faces new for marcasite, was considered. A combination of a new brachydome (021), with a new pyramid (433), gives an approximate hexagonal girdle; but the calculated angles ${ }^{c}$ for such forms are not in close agreement with the measured values.

The specimens were obtained from the oxidized zone of an iron mine in the Carboniferous Mountains of the Teutoburger Wald, near

$a$ A. A. Julien. On the variation of decomposition in the iron pyrites; its cause and its relation to density. Annals N. Y. Acad. Sci., vol. 3, 1884, pp. 365-404; also, vol. 4, 1888, pp. 133-223.

$b$ H. N. Stokes. On pyrite and marcasite. Bull. 186, U. S. Geol. Surv., 1901.

c(001):(021) $=67^{\circ} 57^{\prime}$.

$(001):(433)=68^{\circ} 20^{\prime}$.

$(021):(433)=55^{\circ} 19^{\prime}$.

$(433):(4 \overline{3} 3)=55^{\circ} \quad 1^{\prime}$.

Proc.N.M.vol.39-10-39 
Osnabrück, Hanover, Prussia. Their immediate associate is limonite, resulting from the alteration of siderite, which is regarded by Haarmann, ${ }^{a}$ who studied the geology of the region, as a metasomatic replacement of Permian limestone.

Pseudomorphs of marcasite, after pyrrhotite, have been noted in only a few instances, and chiefly at German localities that have been studied in the utmost detail. From Freiberg, Saxony, such pseudomorphs have been known for a long time. In 1849 marcasite, having the hexagonal prismatic form of pyrrhotite, was described by Breithaupt ${ }^{b}$ as occurring with other sulphides in the "Neuglück," "Drei Eichen," "Alte Elizabeth," "Segen Gottes," "Herzog August," "Besheert Glück," and other mines of this district. Breithaupt's description was quoted by Blum ${ }^{c}$ in 1852 ; the occurrence noted by Frenzel ${ }^{d}$ in 1874; the faces stated by Groth ${ }^{e}$ in 1878 to be (0001) and $(10 \overline{10})$, with an occasional steep hexagonal pyramid; and, finally, the various accounts summarized by Hintze ${ }^{f}$ in 1904. At Nagyag, Siebenburgen, Prussia, according to Blum, ${ }^{g}$ marcasite has been found on dolomite in hexagonal tablets, consisting of base, prism, and pyramid, with the side faces horizontally striated, and coinciding in habit with the pyrrhotite occurring at the same locality.

Rumpf, ${ }^{h}$ in 1870, described pseudomorphs of marcasite after pyrrhotite from one of the iron mines at Loben, near St. Leonhard, Carinthia, Austria, found, according to Weinek, ${ }^{i}$ in a druse at the contact between siderite and limestone. These are rosettes of thin tabular crystals with smooth, regular, lusterless faces, comprising a base, hexagonal prism, and occasional fairly steep pyramid, and were mistaken by Reuss ${ }^{j}$ and Weinek ${ }^{i}$ for pseudomorphs after hematite. Döll, ${ }^{k}$ in 1874 , briefly mentioned tabular pseudomorphs occurring on

$a$ E. Haarmann. Die Eisenerze des Hüggels bei Osnabrück. Zeitschr. fur prakt. Geol., vol. 17, 1909, pp. 343-353. See also Stockfloth. das Eisenerzvorkommen am Hüggel bei Osnabruck., Glückauf, 1894.

$b$ A. Breithaupt. Paragenesis, 1849, pp. 130, 161-164, 170, 253.

$c$ J. R. Blum. Pseudomorphosen des Mineralreichs, 2 Nachtrag, 1853, p. 74.

$d$ A. Frenzel. Mineralogisches Lexicon für das Königreich Sachsen. Leipzig, 1874, p. 201.

$e$ P. Groth. Die Mineraliensammlung. Strassburg, 1878, p. 45.

$f$ C. Hintze. Handbuch der Mineralogie. Leipzig, vol. 1, 1904, p. 637.

$g$ J. R. Blum. Pseudomorphosen des Mineralreichs, 3 Nachtrag, 1863, pp. 192-193. This locality was noted by V. R. v. Zepharovich, Mineralogische Lexicon für das Kaiserthum Oesterreich, Vienna, 1873, p. 202.

$h$ J. Rumpf. Ueber den Magnetkies von Loben bei St. Leonhard in Karnten. Verh. k. k. geol. Reichsanst., Wien, 1870, pp. 2, 3 .

$i$ F. Weinek. Markasit nach Eisenglanz von Loben. Verh. k. k. geol. Reichsanst., Wien, 1867, p. 285.

jA. E. Reuss. Markasit, pseudomorph nach Eisenglanz. Verh. k. k. geol. Reichsanst., Wien, 1867, pp. 218, 219.

$k$ E. Döll. Neue Pseudomorphosen. Tschermak's Min. Mitth., 1874, pp. 85-88. 
blende at Dognacska, Hungary. In 1878 Ain Barber, Algiers, was cited by Groth ${ }^{a}$ as an additional locality, and the accounts of Rumpf, Reuss, and Weinek were summarized by Blum. ${ }^{b}$ Lacroix,$^{c}$ in 1897 , gave an account of marcasite from Pontpéan, near Rennes, Ille-etVilaine, France, describing thin hexagonal plates, with occasional pyramidal habit, as pseudomorphs after pyrrhotite. The same year Miers ${ }^{d}$ mentioned a specimen from Cornwall, England, comprising a low hexagonal pyramid, the material of which "appeared to be marcasite." And, finally, Pojana, Siebenburgen, was added by Hintze ${ }^{e}$ as a further locality.

\section{EXPLANATIONS OF PLATES.}

\section{Plate 63.}

Figs. 1-3.-Crystals of calamine from Chihuahua, Mexico. Orthographic and clinographic projections. Enlarged.

4.-Biotite-phlogopite intergrowth from Ottawa, Canada. Natural size. Clinographic projection, with orthographic plan of upper and lower basal planes. The stippled portion is biotite; the white, phlogopite.

5-6.--Pseudomorphs of marcasite after pyrrhotite from Osnabrück, Prussia. Clinographic projection. Enlarged.

For the significance of the lettering on the figures see text.

\section{Plate 64.}

Pseudomorphs of marcasite after pyrrhotite from Osnabrück, Prussia. About twice natural size.

$a$ P. Groth. Die Mineraliensammlung. Strassburg, 1878, p. 45.

$b$ J. R. Blum. Pseudomorphosen des Mineralreichs. 4 Nachtrag, 1879, p. 105.

$c$ A. Lacroix. Sur la marcasite de Pontpéan (Ille-et-Vilaine) et sur les pseudomorphes qu'elle constitue. Compt. rend., vol. 125, 1897, pp. 265, 267; Bull. Soc. Min. France, vol. 20, 1897, pp. 223-232.

$d$ H. A. Miers. On some British pseudomorphs. Min. Mag., vol. 11, 1897, pp. 263-285.

e C. Hintze. Handbuch der Mineralogie. Leipzig, vol. 1, 1904, p. 827. 


\section{$2 \mathrm{BHL}$ Biodiversity Heritage Library}

Pogue, Joseph E. 1911. "On calamine crystals from Mexico, rutile-mica intergrowth from Canada, and pseudomorphs of marcasite after pyrrhotite from Prussia." Proceedings of the United States National Museum 39(1801), 571-579. https://doi.org/10.5479/si.00963801.39-1801.571.

View This Item Online: $\underline{\text { https://www.biodiversitylibrary.org/item/53443 }}$

DOI: https://doi.org/10.5479/si.00963801.39-1801.571

Permalink: https://www.biodiversitylibrary.org/partpdf/51993

\section{Holding Institution}

Smithsonian Libraries

\section{Sponsored by}

Smithsonian

\section{Copyright \& Reuse}

Copyright Status: Public domain. The BHL considers that this work is no longer under copyright protection.

This document was created from content at the Biodiversity Heritage Library, the world's largest open access digital library for biodiversity literature and archives. Visit BHL at https://www.biodiversitylibrary.org. 